\title{
KAJIAN MOBILITAS PENDUDUK PADA SISTEM TRANPORTASI DARAT PASCA TSUNAMI DI PROPINSI ACEH
}

\author{
Wesli \\ Dosen Jurusan Teknik Sipil, Universitas Malikussaleh \\ email :ir_wesli@yahoo.co.id
}

\begin{abstract}
Abstrak
Rehabilitasi dan rekonstruksi prasarana jalan, jembatan dan perumahan penduduk yang hancur akibat tsunami akan berdampak terhadap pola mobilitas dan kebutuhan perjalanan masyarakat. Relokasi pemukiman menjadi komplek-komplek perumahan yang menjadi sumber bangkitan bagi lalu lintas dan membentuk pola-pola mobilitas tersendiri. Kebutuhan sarana transportasi masyarakat khususnya sepeda motor meningkat pesat seiring dengan mudahnya kepemilikan melalui sistem kredit sehingga tingkat permintaan terhadap sepeda motor khususnya cukup signifikan dan memicu terjadinya kemacetan terutama di pusat-pusat kota baik di propinsi maupun di kabupaten/kota. Metode kajian melalui kajian literatur berdasarkan penelusuran dokumen pada instansi terkait yang dihubungkan terhadap literatur referensi dan teori-teori yang dianalisis secara langsung. Hasil kajian menunjukkan bahwa komplek pemukiman berdampak pada terkonsentrasinya aktivitas penduduk pada suatu wilayah sehingga menimbulkan bangkitan baru, peningkatan mobilitas, peningkatan permintaan kenderaan bermotor yang berakibat kepada terjadinya kemacetan pada ruas-ruas tertentu serta tingginya tingkat kecelakaan di wilayah perkotaan. Aspek manajemen sistem transportasi belum ada upaya pemerintah daerah..Rehabilitasi dan rekonstruksi sangat berpengaruh terhadap aksesibilitas sehingga secara signifikan mendukung pertumbuhan ekonomi di propinsi Aceh
\end{abstract}

Kata Kunci : Mobilitas, Sistem Transportasi

\section{Pendahuluan}

Transportasi merupakan kebutuhan untuk mengatasi disparitas jarak dan komunikasi antara tempat asal dan tempat tujuan sehingga dikembangkan sistem transportasi dan komunikasi dalam wujud sarana (kendaraan) dan prasarana (jalan). Dengan terwujudnya sistem transportasi maka akan dapat menumbuhkan jasa angkutan untuk memenuhi kebutuhan perangkutan (transportasi) dari satu tempat ke tempat lain. Transportasi dan tata guna lahan merupakan dua hal yang tidak dapat dipisahkan, di mana kegiatan transportasi yang diwujudkan dalam bentuk lalu lintas kendaraan, pada dasarnya merupakan kegiatan yang menghubungkan dua lokasi dari tata guna lahan yang mungkin sama atau berbeda yang bermakna bahwa memindahkan orang atau barang dari satu tempat ke tempat lain, berarti memindahkannya dari satu tata guna lahan ke tata guna lahan yang lain, yang berarti pula mengubah nilai ekonomi orang atau barang tersebut.

Propinsi Aceh yang sebelumnya bernama Nanggroe Aceh Darussalam, pada tanggal 26 Desember 2004 dilanda bencana tsunami yang diakibatkan oleh gempa bumi tektonik berkekuatan 8,9 SR berpusat di Samudra Hindia tepatnya pada 2,9 LU dan 95,6 BT di kedalaman $20 \mathrm{~km}$ di laut berjarak sekitar $149 \mathrm{~km}$ selatan kota Meulaboh, Gempa bumi tektonik yang disertai gelombang Tsunami melanda 
beberapa wilayah lepas pantai Indonesia di Aceh dan Nias Sumatera Utara, Jumlah korban tewas akibat gelombang tsunami diperkirakan sebanyak 168.183 jiwa sementara total korban luka-luka sebanyak 124.057 orang. Bencana tersebut meluluh lantakkan sektor sosial, ekonomi, pemerintahan, budaya, dan lainnya, yang ditunjukkan dengan rusaknya 15.000 unit rumah, 12 pelabuhan, $800 \mathrm{~km}$ jalan kabupaten dan desa, $266 \mathrm{~km}$ jalan provinsi, 403 jembatan, 1.052 gedung pemerintah, 755 sekolah, 2 unit rumah sakit, 173 puskesmas, 219 unit pasar, hilangnya mata pencaharian rakyat. Gelombang tsunami telah merusak jaringan jalan maupun jembatan sehingga akses dari satu tempat ketempat lain menjadi lumpuh. Sampai dengan akhir tahun 2006, total jalan yang telah ditangani mencapai $957 \mathrm{~km}$ dan pada tahun 2007 diselesaikan rehabilitasi dan rekonstruksi jalan sepanjang $778 \mathrm{~km}$, sehingga sampai akhir tahun 2007 telah ditangani jalan sepanjang $1.735 \mathrm{~km}$ jalan dengan total biaya mencapai 3,31 trilyun Rupiah.

\section{Tinjauan Kepustakaan}

Menurut Gakenheimer (1999), bahwa masalah-masalah yang mempengaruhi tingkat mobilitas adalah tingkat permintaan kenderaan bermotor, kondisi permintaan lokal yang jauh melebihi kapasitas fasilitas, ketidakcocokan struktur perkotaan dengan peningkatan permintaan kenderaan serta kebutuhan lahan untuk infrastruktur transportasi yang mempunyai hubungan kuat terhadap meningkatnya permintaan kenderaan di kota-kota berkembang, kurangnya pemeliharaan jalan yang memadai dan kesepakatan terbatas antara pejabat yang bertanggung jawab dan berwenang dalam membentuk pendekatan yang tepat terhadap masalah tersebut.

Menurut Tamin (2000), bangkitan perjalanan memiliki pengertian jumlah perjalanan yang dibangkitkan (ditimbulkan) oleh zona pemukiman, baik sebagai asal maupun tujuan perjalanan atau jumlah perjalanan yang dibangkitkan (ditimbulkan) oleh aktivitas pada akhir perjalanan di zona pemukiman, pusat perdagangan, pusat pertokoan, pusat pendidikan, pusat industri dan lain sebagainya. Perumahan baru berarti tempat tinggal tetap atau kediaman yang terdiri dari beberapa rumah yang belum lama selesai dikerjakan (masih baru).

Menurut Mattsson (1999) bahwa rumah tangga membuat pilihan terhadap lokasi (zona dan tipe rumah), kepemilikan mobil/sepeda motor dan pola perjalanan yang diharapkan. Pola perjalanan mencakup frekuensi perjalanan, pilihan tujuan dan pilihan modus untuk beberapa jenis perjalanan. Semua pilihan ini diperlakukan dalam kerangka mikro ekonomi, yang memungkinkan rumah tangga untuk kegiatan bisnis misalnya, aksesibilitas untuk perumahan murah atau lebih baik.

Menurut Meyer (1999), Dalam arti luas bahwa Transportation Demand Management (TDM) adalah tindakan atau serangkaian tindakan yang bertujuan untuk mempengaruhi perilaku perjalanan masyarakat sedemikian rupa sehingga alternatif pilihan mobilitas untuk mengurangi kemacetan. Tiga kategori tindakan tersebut meliputi pelancong menawarkan satu atau lebih moda transportasi alternatif atau jasa yang jumlah penumpang perkenderaan lebih banyak, memberikan insentif/disinsentif untuk mengurangi perjalanan atau untuk mendorong perjalanan pada jam tidak sibuk atau mencapai tujuan perjalanan melalui cara-cara non-transportasi seperti mengganti penggunaan telekomunikasi untuk perjalanan kerja atau belanja 


\section{Batasan dan Metode Kajian}

Metode kajian dilakukan melalui kajian literatur berdasarkan penelusuran dokumen pada instansi terkait yang dihubungkan terhadap literatur referensi dan teori-teori yang dianalisis secara langsung pada tiap bagian pembahasan berdasarkan faktual sebagai bentuk penggambaran kondisi system transportasi pasca tsunami di mana telah dilakukan rehabilitasi maupun rekonstruksi terhadap prasarana jalan dan rencana pemerintah ke depan terhadap sistem transportasi darat di propinsiAceh

\section{Analisis dan Pembahasan}

Sistem transportasi di propinsi Aceh pasca tsunami secara infrastruktur jaringan jalan semakin hari semakin membaik namun seiring dengan perkembangannya dan tingkat mobilitas yang tinggi lambat laun memperlihatkan permasalahan khususnya diperkotaan seperti kota Banda Aceh dan kota Lhokseumawe di mana secara faktual telah menimbulkan kemacetan yang signifikan. Pembangunan infrastruktur tidak diimbangi dengan penataan manajemen dari berbagai aspek termasuk kondisi sosial ekonomi masyarakat sehingga keseimbangan terhadap supply dan demand pada sitem transportasi darat masih perlu mendapat perhatian dari Pemerintah.

\subsection{Mobilitas Penduduk}

Dari data dari Samsat Banda Aceh pada tahun 2010 sampai dengan bulan April jumlah kenderaan baru yang terdaftar bersumber dari hasil penjualan kenderaan bermotor di kabupaten/kota mencapai 46.444 unit. Permintaan sepeda motor di Aceh dari berbagai merek mencapai 11.611 unit/bulan. Kondisi serupa juga terjadi pada jenis mobil mini bus baru yang terdaftar mencapai 1.286 unit. Kondisi ini memperlihatkan bahwa dalam satu bulan, mobil baru yang terdaftar untuk mendapatkan Nomor Polisi BL baru, mencapai 321 unit. Permintaan mobil jenis usaha seperti pick-up pada periode Januari-April 2010, juga tinggi mencapai 522 unit. Permintaan jenis truk sedang mencapai 407 unit dan truk besar 141 unit, namun untuk kenderaan usaha jenis oplet (di Aceh disebut labi-labi) permintaannya masih rendah, dimana dalam periode Januari- April 2010 hanya 47 unit. Sementera untuk kenderaan pribadi jenis sedan, penjualannya tetap tinggi mencapai 131 unit dan jenis jeep 141 unit. Pada satu sisi hal ini merupakan sumber pendapatan daerah yang potensial dari sektor pajak kendaraan bermotor (PKB) dan Bea Balik Nama Kenderaan Bermotor (BBNKB) menyumbang hampir 45 persen lebih dari total Pendapatan Asli Daerah (PAD) Aceh dan merupakan penyumbang terbesar terhadap PAD propinsi Aceh. Sampai bulan April 2010 tercatat penerimaan dari PKB telah mencapai Rp 49,8 miliar atau 34,16 persen dari total target Rp 145,8 miliar. Sementara pada BBNKB mencapai Rp 70,6 miliar atau sebesar 36,49 persen dari targetnya Rp 193,7 miliar. Di sisi lain tingginya permintaan kenderaan bermotor di Aceh berdampak kepada tingginya mobilitas masyarakat pengguna kenderaan khususnya sepeda motor sehingga terjadi kemacetan yang tinggi pada sistem transportasi perkotaan

\subsection{Rumah Tinggal dan Pilihan Perjalan Masyarakat}

Rumah merupakan kebutuhan dasar manusia yang harus dipenuhi. Suatu lokasi perumahan dapat dikatakan baik apabila mempunyai aksesibilitas yang baik 
dan mudah serta aman untuk mencapai tempat kerja (aktivitas). Hal ini berarti sistem transportasi di kawasan perumahan harus diatur dengan sebaik-baiknya.

Lokasi rumah masyarakat yang dibangun oleh pemerintah terletak pada daerah yang bebas bencana tsunami. Perumahan masyarakat yang pada awalnya tersebar diberbagai wilayah kini dibangun dalam bentuk komplek-komplek perumahan sehingga masyarakat terkonsentrasi dan menimbulkan bangkitan baru bagi sistem tranportasi khususnya diwilayah perkotaan. Aktivitas masyarakat untuk bangkit kembali dalam menata perekonomian keluarga mempengaruhi secara perekonomian wilayah. Pertumbuhan ekonomi menyebabkan mobilitas seseorang meningkat melebihi sistem prasarana transportasi yang ada. Kurangnya investasi pada suatu sistem jaringan transportasi dalam waktu yang cukup lama dapat mengakibatkan sistem prasarana transportasi tersebut menjadi sangat rentan terhadap terjadinya lalulintas. Hal ini terjadi karena volume arus lalulintas meningkat melebihi kapasitas jalan yang ada. Perkiraan akan bertambahnya jumlah dan jenis kendaraan yang akan beroperasi dan semakin meningkatnya jumlah angkutan perjalanan dari pusat kota ke perumahan-perumahan harus benar-benar diperhatikan oleh pemerintahan kota, sehingga tuntutan kebutuhan dan pelayanan transportasi dapat terpenuhi. Pemilihan lokasi perumahan juga salah satu faktor yang harus mendapat perhatian khusus, karena kondisi lingkungan perumahan dalam struktur kota akan dapat mempengaruhi perkembangan kota tersebut dan sering menimbulkan masalah-masalah lalulintas seperti kemacetan pada jalur-jalur yang dilewati oleh penduduk perumahan tersebut. Hal yang utama dalam masalah perjalanan adalah adanya hubungan antara tempat asal dan tujuan, yang memperlihatkan adanya lintasan, alat angkut (kendaraan) dan kecepatan. Pola perjalanan di daerah perkotaan dipengaruhi oleh tata letak pusat-pusat kegiatan di perkotaan (permukiman, perbelanjaan, perkantoran, sekolah, rumah sakit, dan lain-lain).

\subsection{Kebijakan Sistem Transportasi}

Secara manajemen sistem transportasi pada wilayah-wilayah yang mempunyai tingkat kemacetan yang tinggi maka perlu diatur atau dibuat kebijakan Transportation Demand Management (TDM) dalam bentuk program Rideshare yaitu penggunaan kenderaan secara bersama-sama misalnya pada suatu komplek perumahan maka pekerja yang mempunyai tujuan dan arah tempat kerja yang sama dapat menggunakan kenderaan secara bersama-sama dari pada menggunakan mobil pribadi masing-masing, hal ini dapat mengurangi kemacetan demikian juga untuk perjalanan ke tempat pendidikan.

Dari perspektif kebijakan publik, TDM memiliki beberapa karakteristik yang mempengaruhi substansi dan ruang lingkup intervensi kebijakan. Pertama, TDM dapat dilihat dari dua skenario pelaksanaan: tindakan yang diterapkan di lokasi tertentu (misalnya di lokasi kerja), atau strategi yang diimplementasikan pada tingkat daerah yang lebih luas

\subsection{Kondisi Transportasi Darat Pasca Tsunami}

Panjang Jalan di seluruh propinsi Aceh adalah $13.819 \mathrm{~km}$ yang berdasarkan wewenang pembinaannya terdiri dari Jalan Nasional wewenang Pemerintah Pusat, 
Jalan Propinsi wewenang Pemerintah Propinsi dan Jalan Kabupaten wewenang Pemerintah Kabupaten/Kota Jalan Nasional seluruhnya mempunyai total panjang $1.782 \mathrm{~km}$ dengan rincian kondisi terdiri dari sepanjang $1.399 \mathrm{~km}$ kondisi mantap, $102 \mathrm{~km}$ kondisi baik, $1.297 \mathrm{~km}$ kondisi sedang, $383 \mathrm{~km}$ tidak mantap, $120 \mathrm{~km}$ kondisi rusak ringan dan 262,8 km kondisi rusak berat. Untuk Jalan Propinsi secara keseluruhan mempunyai total panjang $1.701,8 \mathrm{~km}$ dengan rincian kondisi terdiri dari: $640 \mathrm{~km}$ kondisi mantap, $111 \mathrm{~km}$ kondisi baik, $529 \mathrm{~km}$ kondisi sedang, $1.061 \mathrm{~km}$ kondisi tidak mantap, 96,9 km kondisi rusak ringan dan 964,7 km kondisi rusak berat. Sementara itu Jalan Kabupaten mempunyai total panjang $10.336 \mathrm{~km}$ dengan rincian kondisi terdiri dari $5.974 \mathrm{~km}$ kondisi mantap, $2.978 \mathrm{~km}$ kondisi baik, $2.995 \mathrm{~km}$ kondisi sedang, $4.362 \mathrm{~km}$ kondisi tidak mantap, $3.337 \mathrm{~km}$ kondisi rusak ringan dan $1.024 \mathrm{~km}$ kondisi rusak berat

Tabel 1 Pola Pergerakan Penumpang

\begin{tabular}{|c|c|c|c|c|c|c|c|c|c|c|}
\hline O/D & $\begin{array}{l}\text { Aceh } \\
\text { Selatan }\end{array}$ & $\begin{array}{c}\text { Aceh } \\
\text { Tenggara }\end{array}$ & $\begin{array}{l}\text { Aceh } \\
\text { Timur }\end{array}$ & $\begin{array}{l}\text { Aceh } \\
\text { Tengah }\end{array}$ & $\begin{array}{l}\text { Aceh } \\
\text { Barat }\end{array}$ & $\begin{array}{l}\text { Aceh } \\
\text { Besar }\end{array}$ & Pidie & $\begin{array}{l}\text { Aceh } \\
\text { Utara }\end{array}$ & $\begin{array}{c}\text { Banda } \\
\text { Aceh }\end{array}$ & Oi \\
\hline $\begin{array}{l}\text { Aceh } \\
\text { Selatan } \\
\end{array}$ & - & 30,219 & 23,505 & 22,798 & 927,754 & 55,944 & 24,413 & 46,788 & 367,157 & $1,498,578$ \\
\hline $\begin{array}{l}\text { A.ceh } \\
\text { Tenggara } \\
\end{array}$ & 96,730 & - & 69,084 & 15,645 & 9,547 & 5,670 & 42,691 & 33,244 & 104,701 & 377,312 \\
\hline $\begin{array}{l}\text { Aceh } \\
\text { Timur }\end{array}$ & 32,483 & 35,555 & - & 32,866 & 23,913 & 31,577 & 82,752 & $1,396,687$ & 307,229 & $1,943,062$ \\
\hline $\begin{array}{l}\text { A.ceh } \\
\text { Tengah }\end{array}$ & 43,750 & 46,491 & 20,898 & - & 12,573 & 8,804 & 52,626 & 385,938 & 429,098 & $1,000,178$ \\
\hline $\begin{array}{l}\text { Aceh } \\
\text { Barat }\end{array}$ & 559,697 & 15,483 & 36,498 & 36,242 & - & 58,852 & 38,272 & 74,659 & 340,381 & $1,160,084$ \\
\hline $\begin{array}{l}\text { Aceh } \\
\text { Besar }\end{array}$ & 20,979 & 13,306 & 52,461 & 25,429 & 195,221 & - & 113,965 & 198,150 & 221,801 & 841,312 \\
\hline Pidie & 10,386 & 10,511 & 103,538 & 40,035 & 15,113 & 48,181 & - & $1,584,815$ & 513,403 & $2,325,982$ \\
\hline $\begin{array}{l}\text { Aceh } \\
\text { Utara }\end{array}$ & 224,852 & 99,652 & 745,170 & 235,182 & 136,660 & 156,880 & 165,117 & - & 209,131 & $1,972,644$ \\
\hline $\begin{array}{l}\text { Banda } \\
\text { Aceh }\end{array}$ & 213,949 & 39,729 & 204,267 & 144,706 & $1,190,098$ & 129,429 & 785,004 & 805,303 & - & $3,512,485$ \\
\hline Dd & $1,202,826$ & 290,946 & $1,255,421$ & 552,903 & $2,510,879$ & 495,337 & $1,304,840$ & $4,525,584$ & $2,492,901$ & $4,631,637$ \\
\hline
\end{tabular}

Sumber: Dinas Perhubungan Aceh

Tabel 2 Pola Pergerakan Angkutan Barang

\begin{tabular}{|l|c|c|c|c|c|c|c|c|c|c|}
\hline \multicolumn{1}{|c|}{ O/D } & $\begin{array}{c}\text { Aceh } \\
\text { Selatan }\end{array}$ & $\begin{array}{c}\text { Aceh } \\
\text { Tenggara }\end{array}$ & $\begin{array}{c}\text { Aceh } \\
\text { Timur }\end{array}$ & $\begin{array}{c}\text { Aceh } \\
\text { Tengah }\end{array}$ & $\begin{array}{c}\text { Aceh } \\
\text { Barat }\end{array}$ & $\begin{array}{c}\text { Aceh } \\
\text { Besar }\end{array}$ & Pidie & $\begin{array}{c}\text { Aceh } \\
\text { Utara }\end{array}$ & $\begin{array}{c}\text { Banda } \\
\text { Aceh }\end{array}$ & $\begin{array}{c}\text { Oi } \\
\text { A.Selatan }\end{array}$ \\
\hline A.Tenggara & - & 136,356 & 17,676 & - & 236,453 & - & - & 58,127 & 48,760 & 497,372 \\
\hline A. Timur & - & - & - & - & 53,421 & - & - & - & 112,784 & 166,205 \\
\hline A. Tengah & - & - & - & 19,508 & - & - & 30,712 & 344,429 & 50,623 & 445,272 \\
\hline A. Barat & 702,064 & - & 156,008 & - & - & 624,051 & 45,827 & 6,461 & 28,116 & $1,562,527$ \\
\hline A.Besar & 20,907 & 2,215 & 38,998 & 12,181 & 205,425 & - & 84,353 & 154,521 & 4,774 & 523,374 \\
\hline Pidie & - & - & 61,093 & 41,675 & 27,068 & 102,063 & - & 328,615 & 37,530 & 598,044 \\
\hline A.Utara & 19,508 & 47,759 & 529,876 & $1,267,610$ & 58,075 & 120,419 & 336,401 & - & 191,269 & $2,570,917$ \\
\hline B. Aceh & 16,229 & 8,639 & 150,158 & 19,508 & 188,803 & 780,077 & 75,040 & 75,465 & - & $1,313,919$ \\
\hline \multicolumn{1}{c|}{ Dd } & 758,708 & 194,969 & 953,809 & $1,360,482$ & 769,245 & $1,626,610$ & 623,060 & $1,435,642$ & 527,442 & $8,249,967$ \\
\hline
\end{tabular}

Sumber: Dinas Perhubungan Aceh 
Pola pergerakan barang berdasarkan bangkitan dan tarikan hasil dari survey Origin Destination (OD) yang dilakukan oleh Dinas Perhubungan pada tahun 2006 menunjukkan angka bangkitan terbanyak terjadi di wilayah Banda Aceh dengan jumlah sebesar 3.512.485 orang/trip dan untuk angka tarikan terbanyak terjadi di wilayah Aceh Utara yaitu sebesar 4.525.584 orang/trip. Pola pergerakan penumpang secara keseluruhan di kabupaten/kota pada propinsi Aceh diperlihatkan pada Tabel 1. Di wilayah Aceh Utara dengan jumlah sebesar 2.570.917 trip dan untuk angka tarikan terbanyak terjadi di wilayah Aceh Besar yaitu sebesar 1.626.610 trip. Pola pergerakan barang secara keseluruhan di kabupaten/kota pada propinsi Aceh diperlihatkan pada Tabel 2

Kecelakaan lalulintas tidak mungkin untuk dihilangkan karena berkaitan dengan perilaku manusia namun dapat diminimalisir dengan melakukan treatment melalui kebijakan pemerintah. Untuk mereduksi agar peningkatan keselamatan jalan dapat dilakukan dengan terarah dan mencapai sasaran perlu dilakukan melalui 5 strategi yaitu Engineering, Penegakkan Hukum (Law Enforcement), Public Relations, Pendidikan dan Partisipasi Masyarakat, Pelayanan bantuan gawat darurat dan Evaluasi dan informasi

Jumlah kecelakaan lalu lintas dan kerugian materi di propinsi aceh diperlihatkan pada Tabel 3

Tabel 3 Jumlah Lakalantas dan Kerugian Materi di Propinsi Aceh

\begin{tabular}{|c|r|r|c|}
\hline Tahun & \multicolumn{1}{|c|}{$\begin{array}{c}\text { Jumlah } \\
\text { Laka Lantas }\end{array}$} & $\begin{array}{c}\text { Kenderaan } \\
\text { Terlibat }\end{array}$ & $\begin{array}{c}\text { Kerugian } \\
\text { Materi }\end{array}$ \\
\hline 2003 & 155 & 234 & $737,520,000$ \\
\hline 2004 & 212 & 331 & $833,400,000$ \\
\hline 2005 & 1355 & 366 & $869,040,000$ \\
\hline 2006 & 2152 & 929 & $1,797,195,000$ \\
\hline 2007 & 695 & 1353 & $2,551,810,000$ \\
\hline
\end{tabular}

Sumber: Dinas Perhubungan Aceh

Sementara untuk fatalitas akibat kecelakaan lalu lintas sejak tahun 2001 sampai dengan 2007 di propinsi aceh diperlihatkan pada Tabel 4

Tabel 4 Kecelakaan Lalulintas Berdasarkan Fatalitas

\begin{tabular}{|c|r|r|r|}
\hline Tahun & Meninggal & $\begin{array}{c}\text { Luka } \\
\text { Berat }\end{array}$ & $\begin{array}{c}\text { Luka } \\
\text { Ringan }\end{array}$ \\
\hline 2001 & 104 & 119 & 117 \\
\hline 2002 & 113 & 157 & 216 \\
\hline 2003 & 147 & 148 & 207 \\
\hline 2004 & 196 & 167 & 314 \\
\hline 2005 & 214 & 179 & 148 \\
\hline 2006 & 411 & 746 & 941 \\
\hline 2007 & 505 & 441 & 564 \\
\hline \multicolumn{2}{|c|}{ Sumber: Dinas Perhubungan Aceh } \\
\hline
\end{tabular}

Sumber: Dinas Perhubungan Aceh 


\subsection{Transportasi Sebagai Pendukung Pengembangan Ekonomi Wilayah}

Berdasarkan hasil studi yang dilakukan pemerintah daerah propinsi Aceh terhadap angka perkiraan V/C Ratio seperti diperlihatkan pada Tabel 5 memperlihatkan bahwa pada dasarnya kondisi angkutan darat di propinsi Aceh masih dapat diandalkan sebagai pendukung dari pengembangan ekonomi. Sementara ini untuk sampai tahun 2010 yang diperlukan adalah pemeliharaan saja untuk mempertahankan V/C dan peningkatan berupa pelebaran pada beberapa ruas utama yaitu ruas Banda Aceh-Aceh Besar-Sigli-Bireun-lhokseumawe dan pembangunan ruas Banda Aceh-Lhoknga (Aceh Besar)-Calang (Aceh Jaya)Meulaboh (Aceh Barat). Selain itu juga perlu diperhatikan peningkatan ruas jalan Malahayati-Pidie. Ruas jalan ini adalah satu-satunya akses jalan menuju Kawasan Industri Blang Ulam yang direncanakan oleh BP KAPET. Dengan ditingkatkannya ruas jalan ini, diharapkan dapat mempercepat pertumbuhan Kawasan Industri Blang Ulam tersebut.

Tabel 5 Perkiraan V/C Ratio Jalan Raya Antar Daerah sampai 2010

\begin{tabular}{|c|c|c|c|c|c|c|c|c|}
\hline Asal/Tujuan & $\begin{array}{c}\text { Kota } \\
\text { Sabang }\end{array}$ & $\begin{array}{c}\text { Kota } \\
\text { Banda } \\
\text { Aceh }\end{array}$ & $\begin{array}{l}\text { Kab. } \\
\text { Aceh } \\
\text { Besar }\end{array}$ & $\begin{array}{l}\text { Kab. } \\
\text { Pidie }\end{array}$ & $\begin{array}{c}\text { Kab. } \\
\text { Bireun }\end{array}$ & $\begin{array}{c}\text { Kab. } \\
\text { Aceh } \\
\text { Tengah }\end{array}$ & $\begin{array}{c}\text { Kab. } \\
\text { Aceh } \\
\text { Barat }\end{array}$ & $\begin{array}{r}\text { Kab. } \\
\text { Aceh } \\
\text { Jaya }\end{array}$ \\
\hline \multicolumn{9}{|l|}{ Kota Sabang } \\
\hline Kota Banda Aceh & & & 0,87 & 0,23 & 0,05 & 0,14 & 0,14 & 0,03 \\
\hline Kab. Aceh Besar & & 0,04 & & 0,31 & 0,01 & 0,12 & 0,27 & 0,00 \\
\hline Kab. Pidie & & 0,13 & 0,36 & & 0,09 & 0,50 & 0,05 & 0,00 \\
\hline Kab. Bireun & & 0,01 & 0,01 & 0,01 & & 0,03 & 0,00 & 0,00 \\
\hline Kab. Aceh Tengah & & 0,26 & 0,00 & 0,41 & 0,03 & & 0,00 & 0,00 \\
\hline Kab. Aceh Barat & & 0,04 & 0,80 & 0,08 & 0,00 & 0,01 & & 0,01 \\
\hline Kab. Aceh Jaya & & 0,01 & 0,00 & 0,00 & 0,00 & 0,00 & 0,02 & \\
\hline
\end{tabular}

\subsection{Rencana Pemerintah Aceh terhadap Sistem Transportasi Masa Depan}

Sejalan dengan RTRWN yang ada, dokumen RTRW Provinsi Aceh juga menyusun sejumlah rencana penyediaan infrastruktur yang ditujukan untuk mendukung kegiatan pengembangan ekonomi yang dilakukan dalam wilayah provinsi Aceh secara keseluruhan.

\subsection{1 pembangunan highway (jalan bebas hambatan) Banda Aceh - Medan}

Untuk meningkatkan akses antar propinsi khususnya propinsi Sumatera Utara, Pemerintah berencana melakukan pembangunan highway (jalan bebas hambatan) yang akan menghubungkan Banda Aceh - Medan, Sumatera Utara sepanjang $400 \mathrm{~km}$ dengan empat lajur dan masing-masing dua jalur dengan lebar 60 meter. Investasi terhadap pembangunan jalan tersebut dilakukan oleh Vogo Kora Group yang merupakan gabungan sejumlah perusahaan besar dari Korea Selatan (Korsel) dengan dana investasi tahap awal sebesar Rp 4,5 triliun (US\$ 500 juta) dari perkiraan kebutuhan seluruhnya Rp 20 triliun lebih. Kesiapan Vogo Kora Konsorsium tersebut tertera dalam salah satu pasal Memorandum of Agreement (MOA) antara Pemerintah Aceh Vogo Kora Group. Kesepakatan kerja sama ini merupakan tindak lanjut MoU yang pernah ditandatangani kedua belah pihak pada tahun 2007. Disamping itu juga akan dilakukan pembangunan 
ringroad (jalan lingkar) sepanjang lebih kurang 48 kilometer di Kota Banda Aceh akan menghabiskan anggaran sekitar Rp 1,6 trilun namun kesepakatan tahap awal yang tertuang dalam MoA sebesar US\$20 juta.

\subsubsection{Transportasi Kereta Api}

Kereta Api Aceh dibangun pada 1876 yang pada awalnya sebagai sarana mengangkut peralatan militer dari pelabuhan Ulee Lheue ke Kutaraja atau Banda Aceh dengan kata lain kereta api dibangun untuk kepentingan perang daripada kepentingan ekonomi dan social hingga pada akhirnya juga memberikan keuntungan ekonomi dan politik yang besar. Kereta Api Aceh pernah berjaya melayani jalur Banda Aceh - Medan (Sumatera Utara) sejak penjajahan Belanda sampai dihapuskan dari sistem transportasi yang ada di provinsi Aceh pada tahun 1974. Angkutan kereta api sangat potensial untuk angkutan barang yang murah, khususnya angkutan hasil bumi dan angkutan wisata.

Perkiraan biaya yang dibutuhkan untuk membangun jalan kereta api lintas batas Sumut - Banda Aceh adalah sebesar Rp. 5,8 trilyun untuk skenario sigle track (belum termasuk lokomotif, gerbong, depo). Pada pertengahan bulan Mei 2005 Tim SNCF Perancis telah melakukan studi kelayakan pembangunan kembali kereta api Aceh yang dibiayai oleh SNCF dalam bentuk hibah (grant). Hasil studi dipresentasikan di Banda Aceh pada tanggal 12 Mei 2005 dan dilanjutkan di Jakarta.

Pemerintah Perancis (melalui Misi AFD/Agence FranCaise de Development) telah menyatakan komitmennya untuk membantu pembangunan fisik jalan kereta api Aceh lintas Besitang (Batas Sumut)-Banda Aceh dengan memberikan pinjaman lunak sebesar 169 juta Euro (Rp 2.095.600.000.000,asumsi 1 Euro $=$ Rp 12.400,-) Namun kesepakatan ini masih dalam tahapan Aide Memoire yang perlu ditindaklanjuti. Kebutuhan dana sesuai hasil studi yang telah dilakukan SNCF diperkirakan sebesar 1,082 Milyar Euro (Rp 13.416.800.000.000 asumsi 1 Euro $=\mathrm{Rp} 12.400,-)$ untuk skenario double track, sedangkan untuk skenario sigle track diperkirakan sebesar 672 Juta Euro (Rp 8.332.800.000.000 asumsi 1 Euro = Rp 12.400,-) dengan lintasan Medan-Banda Aceh.

Rencana awal Dirjen Perkeretaapian Departemen Perhubungan RI akan mengoperasikan kereta api Aceh antara bulan April-Juni 2009 melalui penyediaan dana operasi subsidi namun sampai saat ini belum terealisasi karena dalam pengoperasian kereta api di Indonesia oleh PT Kereta Api tidak dikenal istilah bantuan dana subsidi operasi, melainkan hanya public service obligation (PSO). Dari panjang $14 \mathrm{~km}$ rel yang telah dibangun di Aceh, baru siap untuk dioperasikan sepanjang 11,5 km, yaitu dari Krueng Mane-Bungkah (Aceh Utara) ke Krueng Geukuh (Kota Lhokseumawe). Pada tiga lokasi itu juga telah dibangun terminal mini tempat singgah kereta api. Lokomotif dan gerbong kereta api sudah tiba pada Februari 2009 di Krueng Geukuh.

Program Perkeretaapian Aceh merupakan bagian dari program Trans Sumatera Railway Development. Pembangunan jalan kereta api Aceh dianggap solusi tepat saat ini dan juga di masa depan, di mana angkutan kereta api ini 
bersifat massal, murah, aman dan efektif. Pembangunan kembali jaringan pelayanan kereta api Aceh diyakini memberikan dampak positif bagi masyarakat.

\section{Kesimpulan dan Saran}

Berdasarkan hasil kajian di atas maka dapat diambil beberapa kesimpulan dan saran sebagai berikut:

\subsection{Kesimpulan}

Hasil kajian berdasarkan penelusuran dokumen terhadap system transportasi di aceh pasca tsunami dapat disimpulkan sebagai berikut:

1. Pembangunan perumahan/pemukiman penduduk sebagai rumah bantuan dari pemerintah kepada masyarakat korban tsunami yang dibuat dalam bentuk komplek-komplek perumahan/pemukiman berdampak pada terkonsentrasinya aktivitas penduduk pada suatu wilayah sehingga menimbulkan bangkitan baru yang berakibat kepada terjadinya kemacetan pada ruas-ruas tertentu di wilayah perkotaan

2. Pasca tsusnami di Aceh terjadi peningkatan permintaan kenderaan bermotor yang signifikan dengan peningkatan mobilitas penduduk yang tinggi dan mengakibatkan terjadinya kemacetan khususnya di wilayah perkotaan

3. Tingginya mobilitas penduduk berdampak pada tingginya tingkat kecelakaan lalulintas sehingga berimplikasi terhadap terjadinya kerugian materi yang cukup besar

4. Secara manajemen sistem transportasi pada wilayah-wilayah kabupaten/kota mempunyai tingkat kemacetan yang tinggi namun belum ada upaya terhadap kebijakan pemerintah daerah dalam bentuk program seperti program Rideshare yaitu penggunaan kenderaan secara bersama-sama untuk mereduksi tingkat kemacetan, yang dikedepankan hanya penanganan secara infrastruktur

5. Sistem transportasi di Aceh pasca tsunami secara umum belum mengganggu aspek lingkungan, aspek pencemaran seperti polusi udara maupun polusi kebisisngan, kondisinya masih dalam batas normal

6. Rencana pemerintah daerah membangun highway (jalan tol) yang menghubungkan propinsi Aceh (Banda Aceh) dengan propinsi Sumatera Utara (Medan) dan membangun kembali moda jalan Rel (Kereta Api Aceh) sebagai tranportasi masal (mass rapid) merupakan terobosan yang sangat baik untuk meningkatkan aksesibilitas sebagai pendukung pertumbuhan ekonomi Aceh.

7. Rencana pengembangan kawasan secara integrasi dengan membagi kawasan secara potensi yaitu Kawasan Pesisir, Kawasan Tengah dan Kawasan Pedalaman merupakan upaya yang sangat baik sehingga arah pembangunan infrastruktur transportasi yang natinya dapat mendukung aspek perekonomian daerah bisa dilakukan secara berkelanjutan (sustainable) untuk tujuan kesejahteraan rakyat

\subsection{Saran}

Berdasarkan permasalahan yang terjadi dan kesimpulan-kesimpulan di atas dapat disarankan sebagai bentuk rekomendasi sebagai berikut: 
1. Meningkatnya pertumbuhan pergerakan di Provinsi Aceh yang sangat pesat pasca tsunami, khususnya pada ruas jalan Lintas Barat NAD tidak sebanding dengan laju pertumbuhan pembangunan prasarana jalan. Oleh karena itu perlu adanya suatu antisipasi pembangunan suatu ruas jalan yang dapat memberikan pelayanan pergerakan yang efektif dan efisien terhadap pengguna kendaraan

2. Pemerintah daerah perlu membuat kajian terhadap kemacetan dari perspektif manajemen transportasi sehingga nantinya dapat membuat kebijakan-kebijakan dalam bentuk Perda (Qanun) yang mengatur aspek-aspek yang berpengaruh terhadap sistem transportasi dalam bentuk TDM (Transportation Demand Manajemen) sehingga dapat menghasilkan program seperti program Rideshare dalam mengatasi persoalan-persoalan transportasi khususnya persoalan kemacetan.

3. Untuk meningkatkan pertumbuhan ekonomi di propinsi Aceh diharapkan pemerintah daerah dapat memprioritaskan pembangunan jaringan jalan yang strategis terhadap pusat-pusat kegiatan ekonomi

4. Rencana pemerintah daerah terhadap pembangunan highway dan menghidupkan kembali Kereta Api Aceh hendaknya dapat direalisasikan dan pada saat pembangunannya hendaknya selalu memperhatikan aspek lingkungan sehingga tujuan memberikan kesejahteraan (welfare) kepada masyarakat dapat terwujud.

\section{Daftar Kepustakaan}

1. Dinas Perhubungan dan Telekomunikasi Propinsi Aceh, 2007, Data Tansportasi Darat Propinsi Aceh, Pemerintah Daerah Propinsi Aceh

2. Gakenheimer, Ralph, 1999, Urban mobility in the developing world, Department of Urban Studies and Planning, Massachusetts Institute of Technology, 10-403 Cambridge, MA 02139, USA

3. Mattsson, Lars-Goran., Eliasson, Jonas, 1999, A Model For Integrated Analysis of Household Location and Travel Choices, Department of Infrastructure and Planning, Royal Institute of Technology, SE-100 44 Stockholm, Sweden

4. Meyer Michael D, 1999, Demand management as an element of transportation policy: using carrots and sticks to influence travel behavior, School of Civil and Environmental Engineering, Georgia Institute of Technology, Atlanta, GA 30332, USA

5. Tamin,O.Z., 2000, Perencanaan dan Pemodelan Transportasi Edisi Kedua, Institut Teknologi Bandung, Bandung 